\title{
Knowledge, attitudes and practices related to sexually transmitted infections of men in prison
}

\section{Conhecimentos, atitudes e práticas relacionadas às infecções sexualmente transmissíveis de homens em situação prisional}

Conocimientos, actitudes y prácticas relacionadas a las enfermedades de transmisión sexual de hombres en situación de prisión

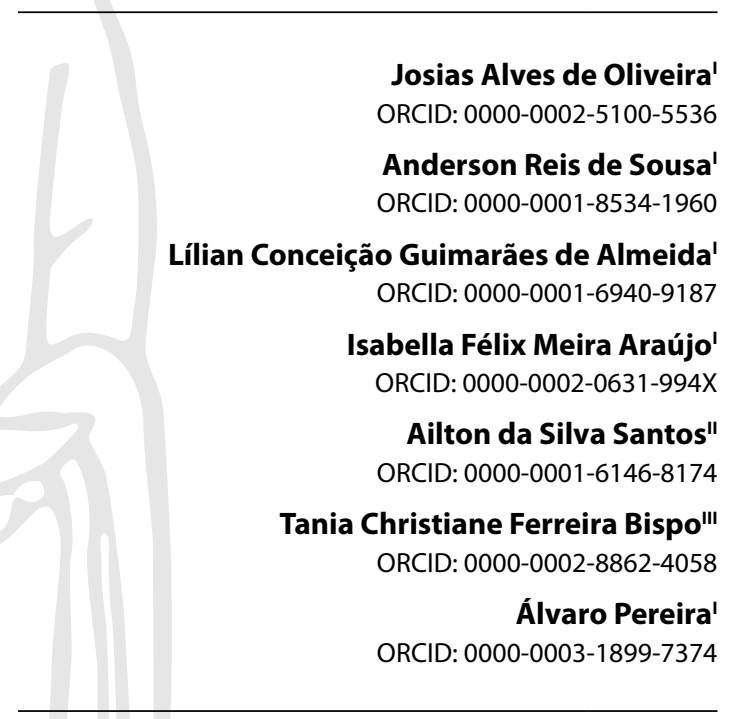

'Universidade Federal da Bahia. Salvador, Bahia, Brazil. "Secretaria de Saúde do Estado da Bahia. Salvador, Bahia, Brazil. "'Universidade do Estado da Bahia. Salvador, Bahia, Brazil.

How to cite this article: Oliveira JA, Sousa AR, Almeida LCG, Araújo IFM, Santos AS, Bispo TCF, et al. Knowledge, attitudes and practices related to sexually transmitted infections of men in prison. Rev Bras Enferm. 2022;75(Suppl 2):e20201273. https://doi.org/10.1590/0034-7167-2020-1273

\section{Corresponding author: \\ Josias Alves de Oliveira \\ E-mail: josiasoliveira88@hotmail.com

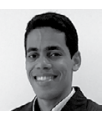

EDITOR IN CHIEF: Dulce Barbosa ASSOCIATE EDITOR: Elucir Gir

Submission: $11-24-2020$

Approval: 08-14-2021

\begin{abstract}
Objectives: to analyze the knowledge, attitudes, and practices related to sexually transmitted infections of men in prison. Methods: qualitative study, based on the methodology Knowledge, Attitude and Practice, conducted with 30 men in prison. The study applied individual interviews submitted to the analyze of the discourse. Results: the incipient knowledge of men was associated with: self-illness and the others', diagnosis, and perception of risk behavior, pervaded by distrust or lack of understanding of the rapid test for detection. The attitudes involved culpability of partnerships, non-adherence to prevention inputs, and resistance to look for health services. The practices are linked to health care after the identification of the disease, use of penile condoms, and attention to the partnership. Conclusions: the reduced knowledge about Sexually Transmitted Infections makes attitudes stereotyped, stigmatized, compromised by the level of education. The level of health care and the limits of deprivation of liberty weaken the practices.

Descriptors: Prisoners; Men; Men's Health; Sexually Transmitted Infections; Knowledge.
\end{abstract}

\section{RESUMO}

Objetivos: analisar os conhecimentos, as atitudes e práticas relacionadas às infecções sexualmente transmissíveis de homens em situação prisional. Métodos: estudo qualitativo, baseado na metodologia Conhecimento, Atitude e Prática, realizado com 30 homens em situação prisional. Aplicou-se entrevista individual submetida à Análise do Discurso. Resultados: o conhecimento incipiente dos homens esteve associado ao: adoecimento próprio e do outro, diagnóstico e percepção do comportamento de risco, perpassado pela desconfiança ou não entendimento do teste rápido para deteç̧ão. As atitudes envolveram culpabilização das parcerias; não adesão aos insumos de prevenção; resistência na procura por serviços de saúde. As práticas vinculam-se ao cuidado à saúde após a identificação da doença, uso de preservativo peniano e cuidado com as parcerias. Conclusões: o reduzido conhecimento sobre Infecções Sexualmente Transmissíveis torna as atitudes estereotipadas, estigmatizadas, comprometidas pelo nível de instrução. As práticas são fragilizadas pelo nível de assistência à saúde e pelos limites da privação de liberdade.

Descritores: Prisioneiros; Homens; Saúde do Homem; Infecções Sexualmente Transmissíveis; Conhecimento.

\section{RESUMEN}

Objetivos: analizar conocimientos, actitudes y prácticas relacionadas a enfermedades de transmisión sexual de hombres en situación de prisión. Métodos: estudio cualitativo, basado en la metodología Conocimiento, Actitud y Práctica, realizado con 30 hombres de la prisión. Aplicada entrevista individual sometida a Análisis del Discurso. Resultados: el conocimiento incipiente de los hombres estuvo relacionado a: propia enfermedad y del otro, diagnóstico y percepción de conducta de riesgo, pasado por desconfianza o no entendimiento del test rápido para detección. Las actitudes envolvieron culpabilización de parejas; no adhesión a insumos de prevención; resistencia a búsqueda por servicios de salud. Las prácticas se vinculan al cuidado de salud tras identificación de la enfermedad, uso de preservativo peniano y cuidado con las parejas. Conclusiones: el reducido conocimiento sobre Infecciones de Transmisión Sexual vuelve las actitudes estereotipadas, estigmatizadas, comprometidas por nivel de instrucción. Las prácticas son debilitadas por nivel de asistencia de salud y límites de privación de libertad.

Descriptores: Prisioneros; Hombres; Salud del Hombre; Enfermedades de Transmisión Sexual; Conocimiento. 


\section{INTRODUCTION}

Currently, the prison situation and its functionality are widely debated in society. Brazil has 1,507 registered prison units, a number that sets it as the third country with the highest number of individuals in prison in the world, around 730 thousand $^{(1)}$. Of these people, about 19,750 are held in prisons of police stations and other custody spaces under the state administration, which make up an occupancy rate of $171.62 \%$. The overcrowding of prisons reaches approximately $45.0 \%$ more people than the total number of vacancies available ${ }^{(1-2)}$, with different occurrences between the Brazilian states, the high number of men in this situation indicates the need for research on this subject.

Authorities question the effectiveness of the prison system since the conditions under which the individuals are exposed put in check the purpose of getting them back and reintegrate them into society, assuming a punitive and non-reintegrative character ${ }^{(3)}$.

The prison situation was created to restrict the rights of freedom and voting; however, it violates other rights ${ }^{(4)}$ such as access to health, bearing in mind the overcrowding of cells, exposure to risks and difficulty in accessing health services, without guarantee of compliance with the principles of the Single Health System of universality, integrality and equity ${ }^{(2)}$.

Nevertheless, some health care is implemented according to interests and strategies of the management, such as the diagnosis of sexually transmitted diseases (STDs), which rapid testing done in prison enables the diagnosis and recognition of the following scenario: high prevalence of HIV, hepatitis B, and $C$ and other sexually transmitted diseases (STDs) ${ }^{(5)}$.

According to the guidelines of the National Policy for Integral Health Care Of Men (NPIHCM), which deals with the promotion, assistance, and recovery of health, it emerges the need to study the topic to understand the development of male care aimed at their sexual health, demand for the organization of health services, training of health professionals and educational actions ${ }^{(6)}$.

Based on this context, the method of knowledge, attitudes, and practices (KAP) ${ }^{(7)}$ it introduces itself as a powerful methodological strategy to collect information and guide the studies in STDs, since health counseling and education play an important role in the prevention, treatment, diagnosis, and control of diseases and can assist the strategies of working with subjects in a prison situation. During the professional care of the prison health team, health problems, especially STDs, are a constant concern in this environment since men have sexual relations without the use of condoms. There are frequent reports of sexual violence, and the signs and symptoms of STDs are always present. In this scenario, it is common for partnerships to become ill and the birth of children with STDs, like congenital syphilis.

Given the panorama presented and anchored in the emerging need to conduct investigations on this phenomenon, the following research question guided this study: What are the knowledge, attitudes, and practices related to sexually transmitted infections of men in prison?

\section{OBJECTIVES}

To analyze the knowledge, attitudes and practices related to sexually transmitted infections of men in prison.

\section{METHODS}

\section{Ethical aspects}

The study is an integrated research project entitled "production of care and social technologies for men's health care and education in the municipality of Salvador, Bahia, Brazil" and is linked to the men's health care line of the group of studies on health care (GSHC) of The Graduate Program in Nursing and Health of the Federal University of the State of Bahia.

Meeting the ethical and scientific requirements contained in resolutions $n^{\circ} 466 / 12$ and n' 510/16 of the National Health Council, the study ensured the confidentiality of the information provided, the anonymity of the interviewees, and the dissemination of the results, using alphanumeric coding of the speeches (from $\mathrm{H} 1$ to $\mathrm{H} 30$ ), representing the order of the interviews.

The Department of Penitentiary Administration and resocialization of the state of Bahia authorized the research the Research Ethics Committee of the School of Nursing of the Federal University of Bahia approved it..

\section{Type of study}

Qualitative study structured in the methodology knowledge, attitudes, and practices (KAP) concerning sexually transmitted infections of men in prison ${ }^{(7)}$.

\section{Scenario and participants of the study}

The research was carried out in a penitentiary complex in the state of Bahia, Brazil, which holds an average occupation of 800 men in prison, on a provisional basis, pending the trial of the offense committed ${ }^{(8)}$.

The study used the guideline SQUARE 2.0 criteria for the design of the research protocol. The researcher and the nurse of the prison health unit in charge by the STD Program jointly selected the inmates to collaborate in the research. The author had no difficulty in articulating contact with the team due to his previous experience as a nurse at the institution.

Thirty men participated in the survey, selected based on the STD Program of the health service of the unit. The collection period was from October 2019 to February 2020. The survey obtained the data through an individual, recorded interview, with the use of a semi-structured script containing questions about the sociodemographic and health characterization in the context of the prison situation and about the understanding about sexual health as well as global health care.

As inclusion criteria, the study select adult men, aged 20 to 59 years, experiencing STDs, under treatment or not, that were imprisoned but had no judicial restrictions (that is, they had no impediments in receiving visits and contact with external persons), and had no difficulty in locomotion to participate in the 
interview, given the difficult access to the space where researcher collected data.

The study excluded men of the prison wards considered more dangerous: men with aggressive behavior, men feeling uncomfortable, and men with unstable health. There was no refusal of men to participate in the survey.

\section{Collection and organization of data}

The study conducted a random approach along with reception, followed by the presentation of the research and the Free and Informed Consent. The research guaranteed, in this process, the reduction of embarrassment and discomfort by presenting the opportunity to collect the fingerprint of those who were illiterate, with subsequent hand sanitization.

The interviews took place in a reserved environment in a health clinic and were attended only by the researcher and the participant. Even following the rules of the system for the preservation of the physical integrity of the researcher, a prison officer supervised the activity through a glass structure in an external environment to the office.

After the interviews, trained researchers with expertise in the field transcribed and manipulated the data and stored it on institutional computers. They organized and systematized it under the support of NVIVO12 software ${ }^{\circ}$. The research used the guidelines of the Consolidated Criteria for Reporting Qualitative Research COREQ to ensure quality and rigor in qualitative research.

\section{Data analysis}

After the organization and codification of the data, the study proceeded to analyze the most illustrative excerpts of the reality experienced by the participants, with the assignment of codes, identification of the central ideas, the assigned meanings, and subsequent elaboration of contextualized discussion. To this end, we used the discourse analysis method (DA) proposed by Michel Pêcheux as a data analysis strategy. In DA, every description is exposed to language misconceptions, and its utterances might generate a displacement of meaning. Then, it is worth noting to observe beyond the truth presented in the subject's speech, transposing into the context experienced by the one who narrates $\mathrm{it}^{(9)}$. The interpretation of the data was carried out through the use of the theoretical assumptions of the knowledge attitudes and practices (KAP) methodology already presented.

This methodology can be used for formative evaluation in the data collection from a portion of the population to favor the elaboration of interventions on a specific topic. In addition, it can highlight knowledge gaps, identify erroneous information, factors that influence behavior, and explain why people act in one way and not another ${ }^{(10)}$. This method also includes of a set of questions to measure what the population knows, thinks, and how it acts regarding a topic ${ }^{(7)}$.

\section{RESULTS}

The KAP methodology was applied to 26 men in prison. The following chart presents sociodemographic, work, and prison situation characteristics.
Next, three categories are arranged in the organization of the results regarding the STDs.

Chart 1 - Characterization of participants, Salvador, Bahia, Brazil, 2020

Sociodemographic, labor, and prison situation characteristics

\begin{tabular}{|c|c|c|}
\hline Sociodemographic & Work & Prison situation \\
\hline $\begin{array}{l}\text { Age group: } 20 \text { to } 59 \\
\text { years - average age } \\
32 \text { years; } \\
\text { Gender identity: } \\
\text { cisgenders; } \\
\text { Sexual orientation: } \\
\text { heterosexuals; } \\
\text { Schooling: literate } \\
\text { during prison } \\
\text { Area of residence } \\
\text { provided for the } \\
\text { arrest: urban; } \\
\text { Marital status: single; } \\
\text { Race/color: black; } \\
\text { Religion: Christian. } \\
\text { Presence of children: } \\
\text { Yes. }\end{array}$ & $\begin{array}{l}\text { Working situation: } \\
\text { they did not carry out } \\
\text { work activities in the } \\
\text { prison system. }\end{array}$ & $\begin{array}{l}\text { Prison situation: } \\
\text { provisional regime - } \\
\text { They were arrested } \\
\text { and are awaiting for } \\
\text { sentencing/acquittal } \\
\text { hearing; } \\
\text { Prison situation time: } \\
\text { more than a year of } \\
\text { seclusion; } \\
\text { Self-reported crimes: } \\
\text { Robbery with the use } \\
\text { of a firearm, followed } \\
\text { by association with } \\
\text { trafficking and } \\
\text { murder. }\end{array}$ \\
\hline
\end{tabular}

Chart 2 - Explanatory model for the theoretical categorization of the study phenomenon, Salvador, Bahia, Brazil, 2020

Knowledge, attitudes and practices related to Sexually

Transmitted Diseases of men in prison

\begin{tabular}{|l|l|l|}
\hline Category $\mathbf{1}$ & Category $\mathbf{2}$ & Category $\mathbf{3}$ \\
\hline $\begin{array}{l}\text { Knowledge related to } \\
\text { STDs of men in prison }\end{array}$ & $\begin{array}{l}\text { Attitudes related to } \\
\text { STDs of men in prison }\end{array}$ & $\begin{array}{l}\text { Practices related to } \\
\text { STDs of men in prison }\end{array}$ \\
\hline
\end{tabular}

\section{Category 1: Knowledge related to Sexually Transmitted Diseases of men in prison}

The study identified the knowledge related to sexually transmitted infections of men in prison as incipient, associated with their illness, the illness of the other, being built through exchanges arising from sexual relations and interaction with people before and after being arrested, the diagnostic opportunity and the perception of risk behavior. The dimensions of (lack of) knowledge, in turn, permeate the non-confidence in/non-understanding of the rapid test for detection.

a) Knowledge developed on the basis of one's illness:

[...] I felt pain, burning and very uncomfortable [...] generated purulent and yellowish discharge [...] it produced a strange smell. $(\mathrm{H} 2)$

[...] like a pus [...] it smelled strong when you took off your underwear [...] it burned when I was putting pus, at the time of urinating. $(\mathrm{H} 6)$ 
[...] I only learned of this HIV due to something unusual that occurred to me. I showed it to my wife, who said, "you have to go to the hospital". But I left it for later because I did not even know what "it" was. I asked my uncle to take me to the doctor. When I got there, I did the examination, and the doctor said to me: "You have HIV and syphilis". (H11)

[...] the disease I first met was gonorrhea. After that, I had the notion that I needed to warn myself. Soon after, I became aware of syphilis, but the main focus was on HIV. It is popularly said that when one has syphilis, wounds from the body and other symptoms arise. ( $\mathrm{H} 18)$

b) Knowledge built on the basis of the illness of the other:

[...] who first found out I had HIV was my wife [...] she had a routine test and tested positive. She came home crying and embarrassed and didn't want to reveal it to me. Then she told me, so I contracted her disease. $(\mathrm{H} 3)$

[...] I learned about sexually transmitted infections after my ex-wife found out she had syphilis and needed treatment. (H21)

[...] I don't know very well. What I learned was from my husband, after he contracted the infection, and also here from my experience in relationships with other men. $(\mathrm{H} 26)$

c) Knowledge arising from the diagnostic opportunity:

[...] before I didn't know it was HIV; I only found out when I was already here in jail. This discovery happened when I needed to perform an examination, and this one stated that I was with HIV. $(\mathrm{H} 3)$

[...] when I went to a unit here in the prison to get a vaccine, they also took the test and diagnosed that I had syphilis [...] if that hadn't happened, I wouldn't have known, as I did not use a condom in relationships. (H5)

[...] I found out what it was, and that I had HIV, syphilis and viral hepatitis when I did the rapid test at the health facility as soon as I got here in prison. $(\mathrm{H} 6)$

[...] I contaminated my wife, but I didn't even know I had the disease, I found out when I was arrested [...] I've already arrived at the prison with symptoms. After that, I found out that I was with a sexually transmitted disease. $(\mathrm{H} 15)$

d) Knowledge developed based on the perception of risk behavior:

[...] or I may have contracted the disease by having had relationships with many women on the street, not knowing if they were already sick and still having sex [...] or it was also because of the fact that I was a user of alcohol and drugs. (H3)

[...] I did this tattoo [...] I continued to paint her with the needle that the guy painted. It seems that it was after this that it happened to me. $(\mathrm{H} 14)$

[...] I needed to think more to answer this question, as I actually had sex with a lot of women, and in none of them I used a condom
[...] within a week, I had a relationship with up to three women and had no knowledge or concern about these sexual diseases. (H19)

e) The dimensions of (lack of) knowledge permeate the non-confidence in/non-understanding of the rapid test for detection:

[...] I do not trust the exams carried out in the prison system [...] the information is very vague, the system is lagging and simple [...] I believe that such an examination is not simple in this way to discover a disease in minutes, especially being a disease such as that caused by the HIV virus. $(\mathrm{H} 1)$

[...] it was some of those tests there. I think it was to my immunity, to see if my immunity was low, you know? The viral load, those things. ( $\mathrm{H} 2)$

\section{Category 2: Attitudes related to Sexually Transmitted Diseases of men in prison}

a) The attitudes of men in prison, before the STDs, permeate the guilt of the partnership for the disease, attitude to meet the demands of partnerships, an attitude of not adhering to prevention inputs, attitude to meet the demands of partnership; an attitude of resistance to diseases; attitude of blaming partnerships for STD:

[...] about sixyears ago, I contracted from a woman. Spots appeared on me, lumps on my leg, on my hands, and my tongue began to come out some strange wounds, which induced me to perform the examination. After I did, they said I was HIV positive. $(\mathrm{H} 2)$

[...] I acquired the disease through a prostitute with whom I had a relationship on the street [...] /affirm this, as it was the only person with whom lexperienced sexual intercourse without a condom [...]. (H4)

[...] I have never had such an infection, but women comment a lot that they have already had [...] because they are women, we men think that they do not have this type of disease, but they are the ones who transmit it (...) this situation also occurred to me. $(\mathrm{H} 10)$

[...] I only became aware of this subject after I had sexual intercourse with a woman I met in a bar [...] I'm sure I contracted her disease. $(\mathrm{H} 15)$

b) Attitude to meet the demands of partnership:

[...] at the time of sex, prostitutes usually talk to use the condom, but transsexuals do not worry and often ask not to use. $(\mathrm{H} 22)$

[...] I try to prevent myself, but usually I cannot [...] inside the jail, there are moments that lack condoms [...] I am forced to have sex without a condom. (H26)

c) Attitude of not adhering to prevention inputs:

[...] I'm anti-condoms. I can't stand condoms, I hate condoms [...] even in my single life, I've never been from getting laid, I've always been very cautious about it, but l've never liked to use a condom. I don't like it. I find this condom business bizarre. $(\mathrm{H} 1)$ 
[...] I don't like to use a condom [...] it causes me awkwardness and bothers me [...] the way to maintain prevention is to maintain a unique relationship, with a single person and perform the exams. $(\mathrm{H} 2)$

[...] man, I think it will spoil my relationship, because to put the condom to have sex with her is very difficult [...] I am doing a treatment and it was a horror for her to accept and have sex with me again as before. We only had sex without the condom. $(\mathrm{H} 4)$

[...] from fouryears to now, we only relate without a condom. $(\mathrm{H} 13)$

[...] I contracted the infection, because, when I had sexual intercourse in the street, it was only "bare bone", without a condom [...]I know that because of this reason, lended up getting infected. $(\mathrm{H} 25)$

d) Attitude of resistance to diseases, resistance to look for health services:

[...] I don't go to see the doctor, I don't get sick, but on the one hand it was good because now I already know, now l just need to take care to avoid the situation to get worse. $(\mathrm{H} 5)$

[...] I don't usually take care of my [...] I never went to the doctor

$[. .$.$] / was just using medicine and treating myself at home. (\mathrm{H} 14)$

[...] I never went to see the doctor or to a health service. $(\mathrm{H} 17)$

\section{Category 3: Practices related to Sexually Transmitted Diseases of men in prison}

The practices of this population of men are related to health care after the disease identification, the use of penile condoms, and the care of the partnership.

a) Health care practices after disease identification:

[...] when I went for the test, they said I had HIV. Then, after that, I was hospitalized for a while taking the right medications, I got better, I went home [...] to this day I take the medicine. All right, at the right time [...] but here I think I have a better care [...] / already have my disease, but if you don't prevent, you'll get tuberculosis, pneumonia, those things you always have in prison, don't you? $(\mathrm{H} 2)$

[...] after the problems I went through with sexually transmitted diseases, I started using condoms [...] now I have conducted the annual examinations for detection of these infections. $(\mathrm{H} 4)$

[...] this is my concern now, how I'm going to treat myself, how I'm going to take exams, how am I going to get my medicine to take care of myself. $(\mathrm{H} 13)$

b) Sexual practices with male condom use:

[...] now I only have sex with a condom [...] since I found out that I got this disease, I start to use it [...] when I get intimate visitation here at the prison, I have used the condom. $(\mathrm{H} 2)$

[...] now when I have sex, I always using the condom [...] if I change person in the relationship, I continue to use the condom even if l am dating. $(\mathrm{H} 3)$ c) The identification of the disease led to care for the partner in the use of condoms and performance of exams that precede the sexual practice:

[...] what I do not want for myself, I do not want for others. I will not "screw" the person. I thought I couldn't kiss my partner; the doctor explained to me that she doesn't take it like this, so I use the condom and then have the relationship. $(\mathrm{H} 10)$

[...] I had already spoken to my wife that she would have to take care of herself because, when I entered here, I went through a sequence of examinations and they detected syphilis [...] And then I explained to her again, and she is also already there treating herself, caring for herself. $(\mathrm{H} 17)$

[...] thinking about taking care of me more than I was and taking care of my wife who may also have this disease and take her to make exams to take care of us together. $(\mathrm{H} 23)$

\section{DISCUSSION}

The speeches of men in prison situation explained the knowledge, attitudes, and practices related to STDs. Even with the silence of male facing the questions applied in the context of the research, or even with the issuance of direct answers, singular expressive elements emerged about the phenomenon investigated in the given context of affective and sexual practices, infectious diseases, gender relations and masculinities, as well as incarceration and experience of the prison situation.

The KAP of men in prison related to STDs is combined with the sociodemographic, educational profile and has much to say about this incarcerated public. Men inmates for more than a year in prison are predominantly young, black or brown, with a low level of education, present physical and mental illness, and deficits in pre-prison living conditions. In Brazil, just by getting into the prison system, men have their health-disease process deteriorated: your health needs are not attended to and/or are neglected, and there are any promotion actions to promote health and prevent diseases and health problems ${ }^{(3-4,11)}$.

In this study, the men's knowledge revealed weaknesses and incipiencies related to sexual experiences and practices experienced. Knowledge about STDs arise from their own illness, the illness of the partners, the sexual act without the use of condoms, the resistance and abandonment of treatments for STDs that affect them during their life trajectories, and not the self-interest in knowing more to prevent themselves.

The study also pointed out the sexual experience with other men inside the prison as a factor of knowledge.

Another point to note is that men pay little attention to public actions related to sexuality, affective and sexual practices, sexual and gender identities that are emerged with self-care for not identifying themselves as agents or subjects of care due to the representations and norms related to the social construction of masculinities ${ }^{(12-13)}$. In addition to the perception for the self-care, men do not recognize each other as sick or vulnerable to illness, which specifically occurs concerning STDs ${ }^{(14)}$.

Men also learned about these diseases through the experience of the illness experience of others. However, given the stigmas 
surrounding STDs, partnerships will not always communicate about the disease, which can make it problematic for the male audience to access information and build knowledge about the subject. Therefore, the diagnosis communication may be complex for both, by possible constraint, stereotype, fear of the reaction of the other and negative feelings ${ }^{(15)}$, what may end up camouflaging the benefits of knowledge and making it inaccessible or taken as irrelevant ${ }^{(16)}$.

In the research field of this study, the prison system has a basic health unit responsible for low-complexity care. As a precautionary measure, the person who is admitted to prison undergoes rapid tests for specific diseases. At this time, men become aware of STDs, and a rapid test becomes an identifier of the disease, a precursor of knowledge and the adoption of practices of care for their health. This finding reinforces the contribution of strategic and programmatic actions in the Single Health System, which expressively involve the performance of nursing professionals in the prevention, control, treatment, and production of knowledge on the subject with key populations.

Regarding the emergence of risk factors that go beyond unprotected sexual intercourse and are directed towards understanding the means of disease transmission, the study showed discursive descriptions about the sharing of personal objects, sharp materials, presence of precipitating/intensifying elements of vulnerability to STDs, such as the abusive use of alcohol and other drugs. This information corroborates studies that point to the following risk factors as determinants of the health needs of men in prison: unsafe sex, drug use, and sharing of cutting material ${ }^{(17)}$.

To that end, the identification of the risks should be a protective factor. However, the permanence of the practices is considered a risk factor to those who share objects. Still, the approach to the theme is more expressive from experience in the prison system, through the health actions implemented in this space, which seems to expand access and the repertoire of male knowledge about the problem.

Nevertheless, the lack of confidence of imprisoned men in the simplicity of the rapid test and the results of the tests done in prison does not seem to modify the behavior of some. For those who believe in the admission tests and who had the tests initially negative and later positive, it represents the milestone of the onset of the disease, helps in identifying the moment in which they contracted, reflecting the risk in sexual relations within the prison.

Some reports showed that the men interviewed blamed the woman for the transmission of the sexually transmitted disease. Preventive measures against STDs go through structured relationships between men and women and their socially constructed attitudes. In sexual intercourse, the use of condoms appears as a decision of the man. This attitude of male dominance involves the subordination of female decisions to males, perpetuates gender inequality, and is influenced by hegemonic masculinity ${ }^{(18)}$.

Knowledge involves distancing from men and not belonging on the topic, assigning a special responsibility to women with whom they have active sexual relations. In this context, when men blame women for the appearance of an STD ${ }^{(19-20)}$, the knowledge seems to be tied to the hegemonic masculinity model, which is based on the idealizations of machismo and induces domination and subordination to women. It also includes permissiveness and social legalization of multiplicities of partnership, and the non-use of protective methods historically delegated to men.

It is strengthened by cultural representations linked to the masculine, such as the ideas of risk, strength, haste, and provision $^{(6)}$. Specifically, such representations can be seen in the way families raise boys without talking about feelings and exposing doubts. In the end, they are educated to be strong, resilient, and hardened. Furthermore, the policies themselves deal with masculinities (heterosexuals) in a way that gender and sexuality continue to be supported by a reductionist logic in which the traditional heterosexual family predominates, having as reference the educational model ${ }^{(21)}$.

The practice of sex without a condom was the general speech among the imprisoned men. The difficulty of negotiating safe sexual practice, inequality of gender relations ${ }^{(22)}$, the possibility of use if the partner is steady or not ${ }^{(23)}$, negative attitudes towards condoms, sexual practice with men ${ }^{(24)}$, and experience of sexuality allied to the illusion of invulnerability ${ }^{(13)}$ can be factors of non-adherence. In addition, the construction of a neglected pattern in choosing sexual partnerships and the lack of dialogue on the subject with friends, for fear of stereotypes also contributes to a departure from the routines of prevention, diagnosis, and treatment ${ }^{(25)}$.

On the other hand, the option for use may be related to high education, free receipt of condoms, education of the mother greater than eight years ${ }^{(24)}$. Individuals with knowledge and positive attitudes facilitate safe actions. However, if there are no conditions that favor behavior change, such as regular access to condoms and acceptance of use for partnerships, its consistent use is not assured ${ }^{(26)}$.

The study emphasizes that the hegemonic standards of masculinity set the man aside from attitudes of care and self-care, which favors the forms of illness and the difficulties in recognizing themselves sick ${ }^{(12-14)}$. Moreover, health policies, including NPIHCM, indicate deficiencies in their plan, maintaining a curative tendency, with a utilitarian, individualized view, blaming men for their distancing from health services ${ }^{(21)}$.

This study revealed that the understanding and the interest of clarification of men in prison concerning STDs occur after the detection of the disease and in contexts arising from the situation of deprivation of liberty and not through the adoption of previous preventive practices. The Brazilian scientific literature reveals that the scope of the health of men in prison is neglected, mainly due to the social and cultural stigma about prison: society condemns them morally, which considerably contributes to the expansion of marginality of these people, having an impact on the production of nursing care ${ }^{(17,27-29)}$. Therefore, many express guilt and self-righteousness in relation to pathology since they reflect the stereotypes received from society. Such a problem can impact men's health literacy and compromise the adoption of healthy and safe care practices ${ }^{(30-31)}$.

When there are signs and symptoms, men reported seeking late medical attention, which may result in discovery of the disease only at an advanced stage. As a significant part of men in Brazil does not present the practice of performing periodic reviews 
to check the health situation when asymptomatic, they do not discover the disease in early stage. In this perspective, self-care is impaired and linked to the manifestation of illness and sporadic/ emergency practices health control ${ }^{(12)}$, which should imply the enhancement of care management actions to cope with STDs in the prison system ${ }^{(3233)}$.

The use of condoms in sexual relations during intimate visits and other relationships within the prison, and the search for the Health Unit for treatment were the health care practiced by men, although it is still discreet among the investigated public. Upon receipt of the diagnosis of STD, some participants of the study expressed concern about the partnerships regarding prevention, which reinforces other findings in the literature regarding the notion of health associated with the disease ${ }^{(15)}$.

Based on the above, communication and health education actions need to be spread to strengthen men's health literacy in the prison system, enhance access to knowledge about the promotion of sexual health, prevention, control, and treatment of STDs, as well as care management based on the construction of positive attitudes to revert them into practices of caring for one's health in the context of incarceration and beyond. Furthermore, nursing and health teams that work in prison systems should be qualified to facilitate dialogue and mutual support between groups of men, mitigate stereotypes and factors that hinder learning, and reduce stigmas and other factors that produce vulnerabilities and inequalities in health, such as the educational deficit.

To minimize the significant increase in STDs in the prison system, it is necessary, therefore, political-managerial measures that guide the planning of actions, health care, intersectoral work, articulated in a network, financing coverage, improving the work management in nursing and health, and ensuring the maintenance of human rights.

\section{Study limitations}

The findings of this study refer to a very specific context, which required a unique data collection technique, and it may have limited the apprehension of other discursive dimensions. The fact that the researchers conducted the interviews under the supervision of a prison officer may have censored the participants' narratives and, therefore, limited the empirical breadth of the findings.

\section{Contributions to the fields of nursing and health}

The results generate advances in the knowledge of Nursing science as far as they are data coming from the life experience of a population with difficult access, providing subsidies for the nursing work directed to the education and empowerment of men in contexts of infectious diseases related to sexual practice. In addition, it meets the Brazilian and international agenda of overcoming inequities in health and defending human rights, so neglected among the prison population in Brazil, contributes to the field of research in the area of gender/masculinities and sexualities, as well as for men's health, confers a meeting of quality findings to guide the clinical practice of nursing workers, particularly in the field of nursing and health management aimed at prison populations, makes efforts to contribute to the advancement of the implementation of focused public health policies.

\section{FINAL CONSIDERATIONS}

The knowledge of men in prison related to sexually transmitted diseases presents a lack of information about sexual health, sexuality, STDs, its means of contagion and transmissibility, prevention and treatment measures, and self-management of care. Attitudes related to STDs are anchored in stereotypes and stigmas, reinforced by machismo, strengthened socioculturally, and intensified in the prison environment, which, consequently, compromises knowledge in welcome of these men and maximizes carelessness with self-care.

In addition, practices related to STDs were discreet and fragile regarding men's competence to self-manage and play the role of the knowledge seized, in coherence with the attitudes, to keep themselves protected. When practicing them, they have a direct link with the experience of illness, without continuity, in a curative logic, but also involve access to socio-emotional and professional support of the health team in the prison.

\section{REFERENCES}

1. Ministério da Justiça e Segurança Pública (BR). Levantamento nacional de informações penitenciárias: junho de 2017 [Internet]. Brasília, DF: MJSP; 2014 [cited 2020 Jul 15]. Available from: http://antigo.depen.gov.br/DEPEN/depen/sisdepen/infopen/relatorios-sinteticos/infopenjun-2017-rev-12072019-0721.pdf

2. Ministério da Justiça e Segurança Pública (BR). Departamento Penitenciário Nacional. Brasília (DF); 2017.

3. Cordeiro EL, Silva TM, Silva LSR, Pereira CEA, Patricio FB, Silva CM. Perfil epidemiológico dos detentos: patologias notificáveis. Av Enferm. 2018;36(2):170-8. https://doi.org/10.15446/av.enferm.v36n2.68705

4. Godoi R. A prisão fora e acima da lei. Tempo Soc. 2019;31(3):141-60. https://doi.org/10.11606/0103-2070.ts.2019.161053

5. Wirtz AL, Yeh PT, Flath NL, Beyrer C, Dolan K. HIV and viral hepatitis among imprisoned key populations. Epidemiol Rev. 2018;40(1):12-26. https://doi.org/10.1093/epirev/mxy003

6. Gomes R, Coordenador. Relatório final de pesquisa: os cuidados masculinos voltados para a saúde sexual, a reprodução e a paternidade a partir da perspectiva relacional de gênero [Internet]. Brasília, DF: MS; 2016[cited 2020 Jun 12]. Available from: https://www.arca.fiocruz.br/ bitstream/icict/15595/2/relatorioSaudeHomemv1.pdf 
7. Instituto Nacional do Desenvolvimento da Educação (BR). Manual do aplicador do estudo CAP [Internet]. Brasília, DF; ME; 2002[cited 2020 Jun 12]. Available from: http://www.unde.gov.mz/docs/monieduca10.doc

8. Secretaria de Administração Penitenciária e Ressocialização. Unidades Prisionais [Internet]. Salvador (BA): SEAP; 2020 [cited 2020 Jun 12]. Available from: http://www.seap.ba.gov.br/index.php/pt-br/unidades

9. Pêcheux M. Semântica e discurso: uma crítica à afirmação do óbvio. 4a ed. Campinas: Unicamp; 2009.

10. Maschi T, Richter M. Human rights and dignity behind bars. J Correct Health Care. 2017;23(1):76-82. https://doi.org/10.1177/1078345816685116

11. Cortez MB, Araujo TZ, Smith MMC. Racionalidade e sofrimento: homens e práticas de autocuidado em saúde. Psicol Saude Doencas. 2017;18(2):556-66. https://doi.org/10.15309/17psd180222

12. Lea-III CH, Gideonse TK, Harawa NT. An examination of consensual sex in a men's jail. Int J Prison Health. 2018;14(1):56-62. https://doi. org/10.1108/JJPH-08-2016-0047

13. Pinheiro MC, Araújo JL, Vasconcelos RB, Nascimento EGC. Health profile of freedom-deprived men in the prison system. Investig Educ Enferm. 2015;33(2):269-79. https://doi.org/10.17533/udea.iee.v33n2a09

14. Sousa AR, Queiroz AM, Florencio RMS, Portela PP, Fernandes JD, Pereira A. Homens nos serviços de atenção básica à saúde: repercussões da construção social das masculinidades. Rev Baiana Enferm. 2016;30(3):1-10. https://doi.org/10.18471/rbe.v30i3.16054

15. Cavalcante EGF, Miranda MCC, Carvalho AZFJT, Lima ICV, Galvão MTG. Partner notification for sexually transmitted infections and perception of notified partners. Rev Esc Enferm USP. 2016;50(3):450-7. https://doi.org/10.1590/S0080-623420160000400011

16. Santos MM, Menezes DDO, Oliveira LLC, Sampaio DC, Rivemales MCC. Perfil das infecções sexualmente transmissíveis em um município do recôncavo baiano. J Nurs Health. 2020;10(3):e20103006. https://doi.org/10.15210/jonah.v10i3.18557

17. Dolan K, Wirtz AL, Moazen B, Ndeffo-Mbah M, Galvani A, Kinner SA, et al. Global burden of HIV, viral hepatitis, and tuberculosis in prisoners and detainees. Lancet. 2016;388(10049):1089-102. https://doi.org/10.1016/S0140-6736(16)30466-4

18. Nascimento IR, Neves ALM, Rodrigues PF, Teixeira E. Representações sociais de masculinidades no curta-metragem "Aids, escolha sua forma de prevenção". Cienc Saude Colet. 2020;25(3):879-90. https://doi.org/10.1590/1413-81232020253.15802018

19. Connell RW, Messerschmidt JW. Masculinidade hegemônica: repensando o conceito. Rev Estud Fem. 2013;21(1):241-82. https://doi. org/10.1590/S0104-026X2013000100014

20. Saldanha JHS, Lima MAG, Neves RF, Iriat JAB. Construção e desconstrução das identidades masculinas entre trabalhadores metalúrgicos acometidos de LER/DORT. Cad Saude Publica. 2018;34(5):e00208216. https://doi.org/10.1590/0102-311x00208216

21. Pereira J, Klein C, Meyer DE. PNAISH: uma análise de sua dimensão educativa na perspectiva de gênero. Saude Soc. 2019;28(2):132-46. https://doi.org/10.1590/s0104-12902019170836

22. Ribeiro LL, Moreira WC, Carvalho ARB, Sousa MCP, Carvalho ML, Castro TMBQ. Vulnerabilidades de pescadores de comunidades ribeirinhas às Infecções Sexualmente Transmissíveis. Rev Cubana Enferm [Internet]. 2017 [cited 2020 Jun 20];33(3):e1231. Available from: http://scielo. sld.cu/pdf/enf/v33n3/1561-2961-enf-33-03-e1231.pdf

23. Gomes R, Murta D, Facchini R, Meneghel SN. Gender and sexual rights: their implications on health and healthcare. Cienc Saude Colet. 2018;23(6):1997-2006. https://doi.org/10.1590/1413-81232018236.04872018

24. Guimarães DA, Oliveira VCP, Silva LC, Oliveira CAM, Lima RA, Gama CA. Dificuldades de utilização do preservativo masculino entre homens e mulheres: uma experiência de rodas de conversa. Estud Psicol (Natal). 2020;24(1):21-31. https://doi.org/10.22491/1678-4669.20190003

25. Silva NEK, Freitas HAG, Sancho LG. Da apreensão de informações aos itinerários terapêuticos de homens diante de suspeita ou com diagnóstico de infecções sexualmente transmissíveis: a internet em pauta. Physis. 2016;26(2):669-89. https://doi.org/10.1590/ S0103-73312016000200016

26. Carvalho RXC, Araújo TME. Knowledge, attitudes and practices of university adolescents about syphilis: a cross-sectional study in the Northeast. Rev Saude Publica. 2020;54:120. https://doi.org/10.11606/s1518-8787.2020054002381

27. Silva NSB, Sousa AR, Souza KBR, Oliveira JA, Pereira Á. Produção do cuidado de enfermagem à saúde de homens em privação de liberdade: discurso coletivo. Enferm Foco. 2020;11(6):78-84. https://doi.org/10.21675/2357-707x.2020.v11.n6.3315

28. Sousa KAA, Araújo TME, Teles SA, Rangel EML, Nery IS. Factors associated with HIV prevalence in a prison population. Rev Esc Enferm USP. 2017;51:e03274. https://doi.org/10.1590/s1980-220x2016040903274

29. Minayo MCS, Ribeiro AP. Health conditions of prisoners in the state of Rio de Janeiro, Brazil. Cienc Saude Colet. 2016;21(7):2031-40. https:// doi.org/10.1590/1413-81232015217.08552016

30. Sánchez Recio R, Ágreda JPAP, Santabárbara Serrano J. [Sexually transmitted infections in male prison inmates: risk of development of new diseases]. Gac Sanit. 2016;30(3):208-14. https://doi.org/10.1016/j.gaceta.2016.01.010 Spanish

31. Hernández-Vásquez A, Rojas-Roque C. Diseases and access to treatment by the Peruvian prison population: an analysis according to gender. Rev Esp Sanid Penit. 2020;22(1):9-15. https://doi.org/10.18176/resp.0002

32. Barbosa ML, Medeiros SG, Chiavone FBT, Atanásio LLM, Costa GMC, Santos VEP. Nursing actions for liberty deprived people: a scoping review. Esc Anna Nery. 2019;23(3):e20190098. https://doi.org/10.1590/2177-9465-EAN-2019-0098

33. Camaduro ACGA, Andrade RLP, Lopes LM, Neves LAS, Catoia EA, Monroe AA. Coordination of care for people living with HIV in the prison system. Acta Paul Enferm. 2020;33:eAPE20190267. https://doi.org/10.37689/acta-ape/2020ao02676 